\section{应業競争力委員会}

アメリカは戦後絶大な国力

を誇り，世界の $1 / 3$ の GNP

を占めるに至った. このため為替レートがドル高に設定さ れていたことが災いし, 国内産業の空洞化が進展し, 日本 との国際競争力が低下した。 日米貿易摩擦がしだいに激し くなり,レーガン大統領は「産業競争力委員会」を組織し， 産業競争力の回復策を諮問した. 1985 年, ヒューレッ ト・パッカード副社長J. A. ヤングが委員長となり, “Global Competition”なる報告書（ヤングレポート）を 提出し, 産学共同体制の強化, 技術移転, ベンチャービジ ネスの育成など，政府を軸にした産業競争力強化策が打ち 出された。冷戦時代には国防研究が中心で，産業育成に無
関心であったとの反省から，産業競争力強化のために，大 学の優れた研究成果を効率的に技術移転する方策が重要と の指摘であった。

その結果, 大学に, 工学研究センター, さらに基礎研究 の技術移転を図るための科学技術センターが多数構築され るようになった，さらに，大統領直轄の科学技術政策局が 超省庁的に体制を組み，重要課題に集中的に対応できるよ うになった. 今日のナノテクノロジー計画もその大きな流 れのひとつである. 円高が 15 年も続いた日本はその逆の 立場にあるといえる。

[766 頁] 弘岡 正明

\title{
JABEE JABEEとは日本技術者教育認定機構〕を修了した者は，「未来の社会を託すことができる人間力
}

(Japan Accreditation Board for Engi- 豊かな技術者として技術業に就くために必要な教育を受 neering Education) の略称で, 工学系の各学協会 が共同して構成している.JABEE の仕事は, 大学などの高等教育機関で実施されている 技術者教育プログラムが，社会の要求水準を満 たしているかどうかを統一基準に基づいて評価し， 要求水準を満たしている専門教育プログラムを認定し, 公表することである.

このような認定制度が求められるようになった理由は, 国際化社会では技術者の資格が各国間で相互承認される必 要があり，そのためには教育の同等性が国際的に認定され ることが必要なためである。こうして認定された教育過程

けた者」と国際的に認知されることになる，どのよ うな教育プログラムがわが国にふさわしく，か

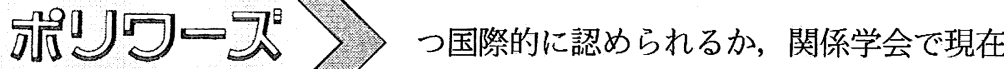
検討されている.したがって，JABEE に認定 されない教育プログラムでは，「社会的に認められ にくい技術者を教育している」という暗黙の逆認定を受 けることになる. その結果, そうした大学への入学希望者 が減り存続が脅かされる懸念があることから，工学部関係 者の多くがその動向を注目している.（本誌 8 月号 pp. 530 ～532 参照)

[773 頁 $]$ 廣瀬 卓司

\section{ポリプロピレンテレフタレート $(\mathrm{PPT})$}

1,3-プロパンジオール（トリメチレングリコール）とテ レフタル酸を原料とする熱可塑性ポリエステルであり，ポ リトリメチレンテレフタレートともいう。ガラス転移温度 $45 \sim 75^{\circ} \mathrm{C}$, 融点 $225^{\circ} \mathrm{C}$ の結晶性ポリマーであり, 熱特性 はナイロン 6 に近い，ポリマー自体はかなり古くから知 られていたが，モノマーである1,3-プロパンジオールが 高価格であったため, 商品化が遅れていた. 1990 年代初 期に Shell Chemical 社がエチレンオキシドとホルムアル デヒド抽よ゙水素からの 1,3-プロパンジオールの低価格
な工業的合成法開発に成功し, PPT の実用的価值が見い だされた，一方，DuPont 社むバイオ技術をベースに，ト ウモロコシの遺伝子組換えによる，1,3-プロパンジオール の工業的合成法を開発している.

PPT の繊維は柔軟性に富み, 弾性回復性に優れるとい う特徴を有する. また, PPT は結晶化速度が大きいためエ ンジニアリングプラスチックとしての射出成形用途や優れ た加工特性を活かしたフィルム用途などへの展開が期待で きる.

[776 頁 $]$ 井上 俊英 